\title{
External and intestinal parasites of the Austral thrush Turdus falcklandii (Aves, Turdidae) in central Chile
}

\author{
Parasitas externos e intestinais do tordo-austral Turdus falcklandii (Aves, Podicipedidae) no Chile \\ Sebastián Llanos-Soto ${ }^{1,2}$; Mabel Córdoba ${ }^{1}$, Lucila Moreno ${ }^{3}$; John Mike Kinsella ${ }^{4}$; Sergey Mironov ${ }^{5}$; \\ Armando Cicchino $^{6}$; Carlos Barrientos ${ }^{7}$; Julio San Martín-Ordenes ${ }^{1}$; Daniel González-Acuña ${ }^{1 *}$

\begin{abstract}
${ }^{1}$ Laboratorio de Parásitos y Enfermedades de Fauna Silvestre, Departamento de Ciencia Animal, Facultad de Ciencias Veterinarias, Universidad de Concepción, Chillán, Chile

${ }^{2}$ Laboratorio de Vida Silvestre, Departamento de Ciencia Animal, Facultad de Ciencias Veterinarias, Universidad de Concepción, Chillán, Chile

${ }^{3}$ Laboratorio de Ecología Parasitaria, Departamento de Zoología, Facultad de Ciencias Naturales y Oceanográficas, Universidad de Concepción, Concepción, Chile

${ }^{4}$ HelmWest Lab, Missoula, Montana USA

${ }^{5}$ Zoological Institute, Russian Academy of Sciences, Universitetskaya Embankment 1, Saint Petersburg, Russia

${ }^{6}$ Universidad Nacional de Mar del Plata, Mar del Plata, Argentina

${ }^{7}$ Escuela de Medicina Veterinaria, Universidad Santo Tomás - USTA, Concepción, Chile
\end{abstract}

Received March 22, 2019

Accepted July 5, 2019

\begin{abstract}
A total of thirty Austral thrushes Turdus falcklandii Quoy \& Gaimard, 1824 (Turdidae) carcasses were brought to the Departamento de Ciencia Animal, Facultad de Ciencias Veterinarias, Universidad de Concepción, to be examined for ecto- and endoparasites. Ectoparasites were found on 20\% (6/30) of the thrushes and belonged to species Brueelia magellanica Cichino, 1986 (Phthiraptera), Menacanthus eurysternus Burmeister, 1838 (Phthiraptera) and Tyrannidectes falcklandicus Mironov \& González-Acuña, 2011 (Acari). Endoparasites were isolated from 26.6\% (8/30) of the birds and identified as Lueheia inscripta Westrumb, 1821 (Acanthocephala), Plagiorhynchus cylindraceus Goeze, 1782 (Acanthocephala), Wardium sp. sensu Mayhew, 1925 (Cestoda), Dilepis undula (Cestoda) Schrank, 1788, and Zonorchis sp. (sensu Travassos, 1944) (Trematoda). To our knowledge, all endoparasites collected in this study are new records in T. falcklandii and expand their distributional range to Chile.
\end{abstract}

Keywords: Acanthocephala, Acari, Cestoda, Phthiraptera, Trematoda, Turdidae.

\section{Resumo}

Um total de trinta carcaças do tordo-austral Turdus falcklandii Quoy \& Gaimard, 1824 (Turdidae) foi encaminhado ao Departamento de Ciência Animal, Facultad de Ciencias Veterinarias, Universidad de Concepción, para ser examinado quanto a presença de parasitas externos e internos. Parasitas externos foram encontrados em 20\% (6/30) dos tordos inspecionados e identificados como Brueelia magellanica Cichino, 1986 (Phthiraptera), Menacanthus eurysternus Burmeister, 1838 (Phthiraptera), e Tyrannidectes falcklandicus Mironov \& González-Acuña, 2011 (Acari). Parasitas internos foram identificados em 26,6\% (8/30) dos espécimes examinados como Lueheia inscripta Westrumb, 1821 (Acanthocephala), Plagiorhynchus cylindraceus Goeze, 1782 (Acanthocephala), Wardium sp. sensu Mayhew, 1925 (Cestoda), Dilepis undula sensu Schrank, 1788 (Cestoda) e Zonorchis sp. (sensu Travassos, 1944) (Trematoda). Tanto quanto é do nosso conhecimento, todos os parasitas internos coletados neste estudo pertencem a novos registros em T. falcklandii e com expansão de sua distribuição para o Chile.

Palavras-chave: Acanthocephala, Acari, Cestoda, Phthiraptera, Trematoda, Turdidae.

*Corresponding author: Daniel González-Acuña. Laboratorio de Parásitos 


\section{Introduction}

The family Turdidae is composed of more than 300 species distributed on most continents. Only five thrush species have been recorded in Chile: The veery Catharus fuscescens Stephens, 1817; the wood thrush Hylocichla mustelina Gmelin, 1789; the Chiguanco thrush Turdus chiguanco Lafresnaye \& d'Orbigny, 1837; the creamy-bellied thrush T. amaurochalinus Cabanis, 1851; and the Austral thrush T. falcklandii Quoy \& Gaimard, 1824, with only T. chiguanco and T. falcklandii being residents (MARTÍNEZ \& GONZÁLEZ, 2004). Turdus falcklandii is an abundant bird of urban and rural areas of Chile, including city gardens and orchards (CHESTER, 2008) and Nothofagus forests of the central and south areas of the country (JARAMILLO, 2005; CHESTER, 2008). It is an omnivorous species, spending most of its time feeding from fruits on trees or preying on invertebrates on the ground (ROZZI et al., 1996). It is distributed from Antofagasta $\left(23^{\circ} 37^{\prime} \mathrm{S}, 70^{\circ} 23^{\prime} \mathrm{W}\right)$ to Cape Horn (55 $\left.59^{\prime} \mathrm{S}, 67^{\circ} 15 \mathrm{~W}\right)$, with subspecies T. f. magellanicus (King 1831) ranging from Chañaral $\left(26^{\circ} 20 \mathrm{~S}, 70^{\circ} 37 \mathrm{~W}\right)$ to Cape Horn and T. $f$. mochae (Chapman, 1934) found only in the Isla Mocha National Reserve (38 22' S, 735' W) (CHESTER, 2008).

Currently, T. falcklandii does not face any conservation issues with a stable population size and large distributional range. However, there is a lack of information about parasites carried by this species. To this date, the only descriptions of ectoparasites are Dasypsyllus stejnegeri Smit, 1976 (Siphonaptera: Ceratophyllidae) in the Falkland/Malvinas Islands (HASTRITER \& SCHLATTER, 2006), Tyrannidectes falcklandicus Mironov \& González-Acuña 2011 (Acari: Proctophyllolidae) in central Chile (MIRONOV \& GONZÁLEZ-ACUÑA, 2011), Ixodes auritulus Neumann, 1904 (Acari: Ixodidae) in southern Chile (GONZÁLEZ-ACUÑA et al., 2005), Brueelia magellanica Cicchino, 1986 (Phthiraptera: Philoptheridae) in central Chile (CICCHINO, 1986; GONZÁLEZACUNA et al., 2006), and Menacanthus eurysternus Burmeister, 1838 (Mallophaga: Menoponidae) in central and southern Chile (GONZÁLEZ-ACUÑA et al., 2006). Regarding endoparasites, Hymenolepis fernandensis Nybelin, 1929 (Cestoda: Hymenolepididae) was described on Robinson Crusoe Island (Chile), the only internal parasite documented for this thrush (NYBELIN, 1929). The main purpose of this study is to identify ecto- and endoparasites of the Austral thrush T. falcklandii in Chile.

\section{Materials and Methods}

Thirty thrush carcasses were collected in different localities of the Biobío region, Chile, in the period 2004-2010. Carcasses were brought to the Departamento de Ciencia Animal, Facultad de Ciencias Veterinarias, Universidad de Concepción, Chillán, and stored at $-20^{\circ} \mathrm{C}$ until examination. Thrushes examined in this study died of anthropogenic causes common to birds living in the countryside, such as poisoning, dog attacks, and illegal hunting.

External inspection of carcasses included a rigorous examination of their feathers in search of ectoparasites. Specimens found were preserved in ethanol $(70 \%)$ for future identification. Lice (Phthiraptera) collected were processed using $\mathrm{KOH}(20 \%)$ and dehydrated in a series of alcohols (40, 80 and 100\%) and then mounted using Canada balsam as described in Price et al. (2003). Mites (Acari) were cleared using Nesbitt's solution ( $40 \mathrm{~g}$ of chloral hydrate, $25 \mathrm{~mL}$ of distilled water and $2.5 \mathrm{~mL}$ of hydrochloric acid) for $72 \mathrm{~h}$ and were later mounted in Berlese solution (KRANTZ, 1978). Ectoparasites species and sex were identified using keys indicated in Burmeister (1838) and Cicchino (1986, 1987). To evaluate the presence of endoparasites, thrushes were necropsied following procedures described in Kinsella \& Forrester (1972). Acanthocephala were cleared in temporary mounts of $80 \%$ phenol, identified, and then returned to the preservative. Cestodes and trematodes were and stained in Semichon's carmine stain and mounted in Canada balsam (PRITCHARD \& KRUSE, 1982). Helminths were identified following descriptions in Yamaguti (1958, 1959, 1963) and Khalil et al. (1994).

Basic population parameters of prevalence, mean intensity, range, and mean abundance were calculated for ectoparasites and endoparasites collected. Prevalence was defined as the percentage of hosts infested by a particular parasite species. Mean intensity is represented by the mean number of parasites found in infected hosts. Range is the difference in the number of parasites collected in the most and least infested/infected hosts. Mean abundance is the number of individuals of a particular parasite from single host. Calculations were performed according to Bush et al. (1997). Additionally, ecto- and endoparasites collected were digitally measured using KS100 Imaging system 3.0 (Carl Zeiss Vision GmbH, Hallbergmoos, Germany).

\section{Results and Discussion}

\section{Ectoparasites}

Ectoparasites were present on 20\% (6/30) of the thrushes examined. Lice were identified on $20 \%(6 / 30)$ with a total of 672 individuals collected. Mites were found on $3.3 \%(1 / 30)$ of the birds examined with only a single specie of mite collected. Population parameters for ectoparasites are indicated in Table 1.

\section{Phthiraptera}

\section{Brueelia magellanica}

Brueelia is a diverse genus composed of approximately 276 species (CICCHINO \& CASTRO, 1998; PRICE et al., 2003). In South America, 37 representatives of the genus have been documented to parasitize birds of the families Icteridae, Emberizidae, Mimidae, Thraupidae, Turdidae, and Picidae (CARRIKER, 1963; CICCHINO, 1979, 1982, 1983, 1986, 1990, 2004; CASTRO \& CICCHINO, 1996; CICCHINO \& CASTRO, 1996; GONZÁLEZ-ACUÑA et al., 2006; VALIM \& PALMA, 2006; CICCHINO \& GONZÁLEZ-ACUÑA, 2008, 2009; CUNHA et al., 2013; GOMEZ-PUERTA \& CRIBILLERO, 2015; VALIM \& CICCHINO, 2015). In this study, the presence of $B$. magellanica was found in T. falcklandii (Figure 1). A total of 10 males, 13 females (23 adults), and 6 nymphs were identified with a female/male ratio of 1.3 and a nymph/adult ratio of 0.2. Body measures for B. magellanica are indicated in Table 2. 
Brueelia magellanica has been previously recorded for T. falcklandii in Argentina and south-central Chile (CICCHINO, 1986; CICCHINO \& CASTRO, 1996; GONZÁLEZ-ACUÑA et al., 2006). González-Acuña et al. (2006) suggest that B. magellanica has a broader distribution in Chile and parasitizes more Turdidae. They also indicate that many other Brueelia species are probably present on Chilean birds.

\section{Menacanthus eurysternus}

The genus Menacanthus Neumann, 1912 is composed of 94 parasite species hosted by birds from the orders Pelecaniformes, Passeriformes, Piciformes, Tinamiformes, and

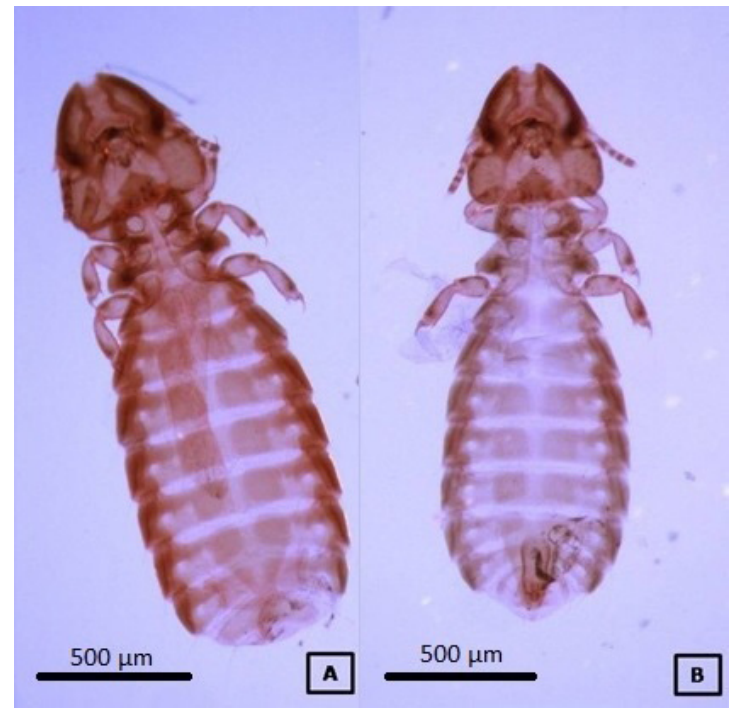

Figure 1. Female (A) and male (B) adult Brueelia magellanica (100x magnification).
Galliformes (PRICE et al., 2003; PRICE, 1975; PRICE \& EMERSON, 1975; PRICE et al., 2003). In South America, a total of 34 genus have been reported parasitizing birds from the families Cracidae, Tinamidae, Ramphastidae, Odontophocidae, Picidae, Galbulidae, Tyrannidae, Thraupidae, Pipridae, Turdidae, Grallariidae, Capitonidae, Mimidae, Cardinalidae, Icteridae, and Troglodytidae (PRICE, 1975; PRICE \& EMERSON, 1975; PRICE et al., 2003; KUABARA \& VALIM, 2017). The presence of $M$. eurysternus was accounted in the thrushes examined with 343 males, 128 females (471 adults), and 172 nymphs identified and a female/male ratio and nymph/adult ratio of 2.67 and 0.4 , respectively (Figure 2). Body measurements for both $B$. magellanica and $M$. eurysternus are indicated in Table 2 . González-Acuña et al.

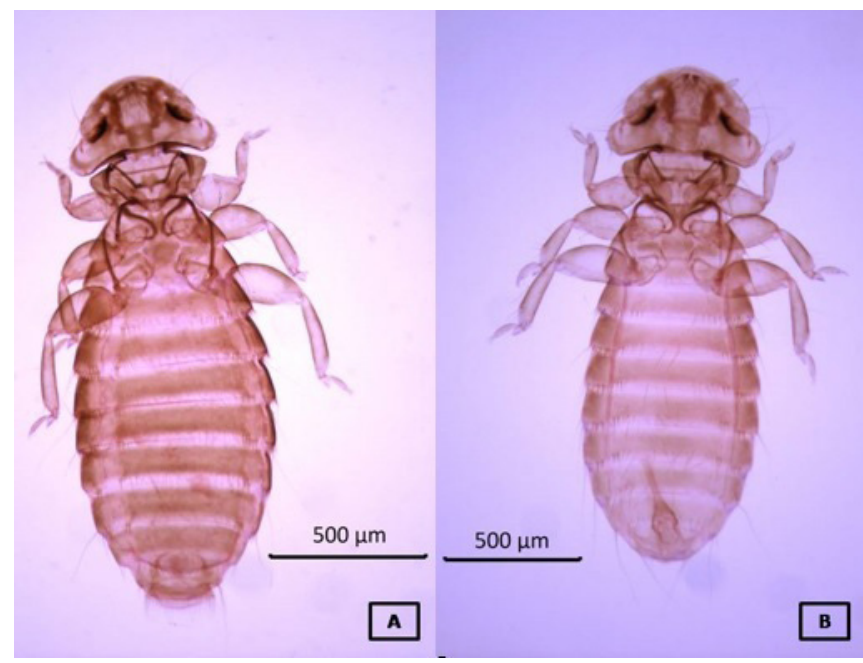

Figure 2. Female (A) and male (B) adult Menacanthus eurysternus (100x magnification).

Table 1. Range, mean intensity, mean abundance and prevalence of ectoparasites collected from the Austral thrush (Turdus falcklandii), Chile.

\begin{tabular}{lcccccc}
\hline \multicolumn{1}{c}{ Species } & $\begin{array}{c}\mathbf{N}^{\circ} \text { of birds } \\
\text { examined }\end{array}$ & Positive birds & $\begin{array}{c}\mathbf{N}^{\circ} \text { of } \\
\text { parasites } \\
\text { collected }\end{array}$ & Range & $\begin{array}{c}\text { Mean } \\
\text { intensity }\end{array}$ & $\begin{array}{c}\text { Mean } \\
\text { abundance }\end{array}$ \\
\hline $\begin{array}{l}\text { Phthiraptera } \\
\text { Brueelia magellanica }\end{array}$ & 30 & 3 & 29 & $2-25$ & $9.7 \pm 13.3$ & $0.97 \pm 4.6$ \\
Menacanthus eurysternus & 30 & 5 & 643 & $2-266$ & $128.6 \pm 136.0$ & $21.43 \pm 70.2$ \\
$\begin{array}{l}\text { Acariformes } \\
\text { Tyrannidectes falcklandicus }\end{array}$ & 30 & 1 & 30 & $1-30$ & $30 \pm 5.5$ & 10.0 \\
\hline
\end{tabular}

Table 2. Mean body measures $(\mu \mathrm{m})$ of Brueelia magellanica and Menacanthus eurysternus collected from the Austral thrush (Turdus falcklandii), Chile.

\begin{tabular}{|c|c|c|c|c|c|c|c|c|}
\hline \multicolumn{5}{|c|}{ Brueelia magellanica } & \multicolumn{4}{|c|}{ Menacantus eurysternus } \\
\hline \multirow{2}{*}{$\begin{array}{c}\text { Sex } \\
\text { Body structure }\end{array}$} & \multicolumn{2}{|c|}{ Male $(n=10)$} & \multicolumn{2}{|c|}{ Female $(n=13)$} & \multicolumn{2}{|c|}{ Male $(n=128)$} & \multicolumn{2}{|c|}{ Female $(n=343)$} \\
\hline & Length & Width & Length & Width & Length & Width & Length & Width \\
\hline Head & 396 & 396.2 & 416.25 & 412.87 & 456.99 & 466.98 & 273.67 & 508.09 \\
\hline Thorax & 118.4 & 260.2 & 155.75 & 385.38 & 166.53 & 354.30 & 178.86 & 388.80 \\
\hline Pterothorax & 98.2 & 345.9 & 150.12 & 351.45 & 106.26 & 340.41 & 115.17 & 342.62 \\
\hline Abdomen & 990.6 & 559 & 1176.3 & 616.62 & 967.86 & 545.99 & 1169.92 & 640.07 \\
\hline Genitalia & 195 & & & & 375.75 & & & \\
\hline
\end{tabular}


(2006) previously recorded $M$. eurysternus on $T$. falcklandii in Chile. The louse $M$. eurysternus is a cosmopolitan and generalist parasite of 176 bird species from 20 families around the world (PRICE et al., 2003). In America, it has been found on Sturnus vulgaris (Sturnidae), Colaptes auratus (Picidae), Cyanocitta cristata (Corvidae), Pica hudsonia (Corvidae), Turdus migratorius (Turdidae), Passer domesticus (Passeridae), Acanthis flammea (Fringillidae), Quiscalus quiscula (Icteridae), and Icterus galbula (Icteridae) in Canada (PRICE, 1975; FAIRN et al., 2014; GALLOWAY et al., 2014); Peucaea carpalis (Emberizidae), Aphelocoma coerulescens (Corvidae), C. cristata, C. stelleri, Cyanocorax yncas (Corvidae), Pica pica (Corvidae), Cardinalis cardinalis (Cardinalidae), Pheucticus ludovicianus (Cardinalidae), P. domesticus, S. vulgaris, Junco hyemails (Passerellidae), Pipilo chlorurus (Passerallidae), Seiurus aurocapilla (Parulidae), Setophaga ruticilla (Parulidae), Toxostoma bendirei (Mimidae), Tx. redivivum, Tx. rufum, Mimus polyglottos (Mimidae), Molothrus aeneus (Icteridae), M. ater, I. galbula, Q. quiscula, Agelaius phoeniceus (Icteridae), Dryobates pubescens (Icteridae), H. mustelina, T. migratorius, Sialia mexicana (Turdidae), Zonotrichia leucophrys (Passerellidae), and Z. querula in the United States (PRICE, 1975; NELDER \& REEVES, 2005); Chlorospingus flavopectus (Passerellidae), Arremon brunneinucha (Passerellidae), Mitrospingus cassinii (Thraupidae), Tangara dowii (Thraupidae), Turdus assimilis (Turdidae), T. grayi, and T. nigrescens in Costa Rica (PRICE, 1975; LINDELL et al., 2002; SYCHRA et al., 2007; MARTINU゚ et al., 2015), Thraupis bonariensis bonariensis (Thraupidae), T. amaurochalinus and Manacus manacus (Pipridae) in Argentina (CASTRO \& CICCHINO, 1978, 1996; CICCHINO, 2007); Manacus manacus, Turdus leucomelas, T. amaurochalinus, and T. rufiventris in Brazil (ENOUT et al., 2009; CUNHA et al., 2013; MARTINU゚ et al., 2015); Grallaria ruficapilla (Grallaridae) and Eubucco richardsoni (Capitonidae) in Peru (PRICE, 1975; CLAYTON et al., 1992); Chiroxiphia lanceolata (Pipridae), Grallaria quitensis (Grallaridae), Mimus gilvus (Mimidae), and Pelecanus occidentalis (Pelecanidae) in Colombia (PRICE, 1975; PARRA-HENAO et al., 2011); M. gilvus in Venezuela (PRICE, 1975), M. polyglottos in Cuba (PRICE, 1975); and T. amaurochalinus in Bolivia (PRICE, 1975).

\section{Acari}

\section{Tyrannidectes falcklandicus}

The genus Tyrannidectes Mironov, 2008 (Analgoidea: Proctophyllolidae) appears to be restricted to passerine birds of the New World, with eleven species distributed along the American continent (VALIM \& HERNANDES, 2010; MIRONOV \& GONZÁLEZ-ACUÑA, 2011). Previous reports detail the presence of Tyrannidectes crassus Trouessart, 1885; Tyrannidectes pteroptochi Mironov \& González-Acuña, 2015; Tyrannidectes anairetes Mironov \& González-Acuña, 2011; Tyrannidectes cinclodes Mironov \& González-Acuña, 2011; Tyrannidectes berlai Mironov, 2008; Tyrannidectes fissuratus Hernandes \& Valim, 2005; Tyrannidectes synallaxis Hernandez et al., 2016; Tyrannidectes amaurochalinus Hernandes \& Valim, 2006; and Tyrannidectes reticulatus Černý, 1974 in South America (TROUESSART, 1885; MIRONOV et al.,
2008; VALIM \& HERNANDES, 2008; VALIM \& HERNANDES, 2010; BARRETO et al., 2012; ENOUT et al., 2012; MIRONOV \& GONZÁLEZ-ACUÑA, 2015; HERNANDES et al., 2016); T. berlai in Central America (SARI et al., 2013); and T. banksi in Sayornis phoebe (Tyrannidae) in North America (VALIM \& HERNANDES, 2010; GALLOWAY et al., 2014).

Tyrannidectes falcklandicus Mironov \& González-Acuña, 2011 was the only mite species identified on T. falcklandii in this study (Figure 3). Mironov \& González-Acuña (2011) have previously recorded T. falcklandicus on Turdus falcklandii in Chile.

\section{Endoparasites}

Of the birds examined, $26.6 \%(8 / 30)$ were host to at least one kind of endoparasite. Two Acanthocephala, two Cestoda, and a single Trematoda were identified. Population parameters for endoparasites are indicated in Table 3.

\section{Acanthocephala}

\section{Lueheia inscripta}

The genus Luehia Travassos, 1920 (Acanthocephala: Plagiorhynchidae) is composed of only four species present in the American continent, L. adlueheia Werby, 1938 in North America; L. cajabambensis Machado \& Ibañez, 1967 and L. lueheia Travassos, 1919 in South America; and L. inscripta Westrumb, 1821 reported in North, Central and South America (GOLVAN, 1994; SALGADO-MALDONADO \& CASPETA-MANDUJANO, 2010). Lueheia inscripta (Figure 4) was found in 6.7\% (2/30) of the thrushes. This acanthocephalan parasitizes birds mainly from the Turdidae family but also infects lizards and anurans as paratenic hosts (TRAVASSOS, 1926; WHITTAKER et al., 1970; ACHOLONU, 1976). Information about the life cycle

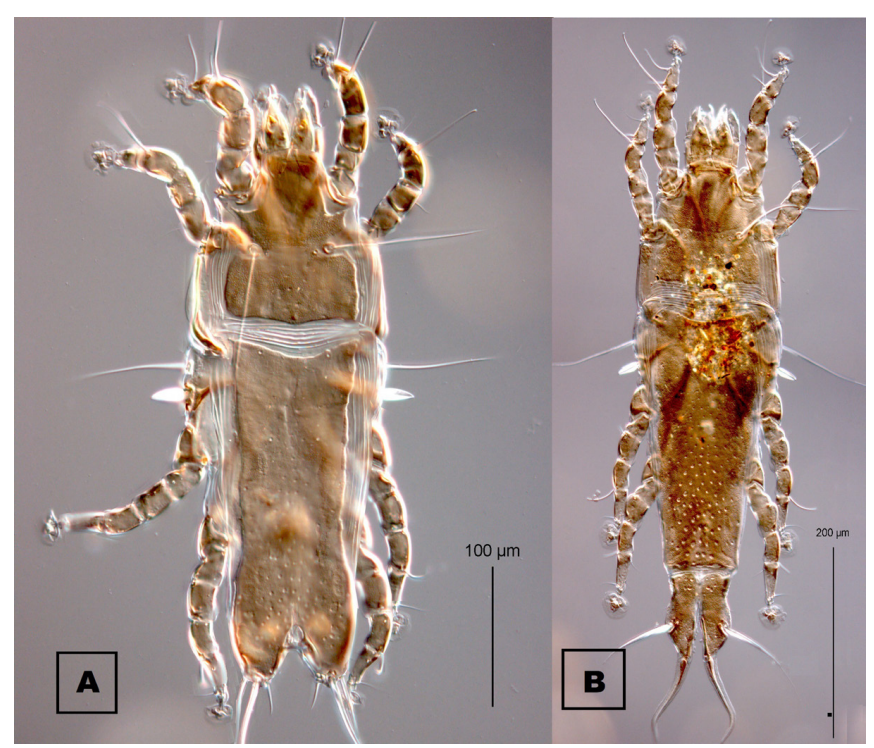

Figure 3. Male (A) and female (B) adult Tyrannidectes falcklandicus (400x magnification). 
Table 3. Range, mean intensity, mean abundance and prevalence of endoparasites collected from the Austral thrush (Turdus falckandii), Chile.

\begin{tabular}{lcccccc}
\hline \multicolumn{1}{c}{ Species } & $\begin{array}{c}\mathbf{N}^{\circ} \text { of birds } \\
\text { examined }\end{array}$ & Positive birds & $\begin{array}{c}\mathbf{N}^{\circ} \text { of } \\
\text { parasites } \\
\text { collected }\end{array}$ & Range & $\begin{array}{c}\text { Mean } \\
\text { intensity }\end{array}$ & $\begin{array}{c}\text { Mean } \\
\text { abundance }\end{array}$ \\
\hline $\begin{array}{l}\text { Acantocephala } \\
\text { Lueheia inscripta }\end{array}$ & 30 & 2 & 34 & $1-22$ & $17 \pm 14.8$ & $1.13 \pm 4.0$ \\
$\begin{array}{l}\text { Plagiorhynchus cilindraceus } \\
\text { Cestoda }\end{array}$ & 30 & 2 & 7 & $3-4$ & $3.5 \pm 0.7$ & $0.23 \pm 0.9$ \\
$\begin{array}{l}\text { Wardium sp. } \\
\text { Trematoda }\end{array}$ & 30 & 6 & 27 & $1-11$ & $4.5 \pm 1.4$ & $0.9 \pm 2.7$ \\
\begin{tabular}{l} 
Zonorchis sp. \\
\hline
\end{tabular} & 30 & 1 & 1 & $1-1$ & & 20 \\
\end{tabular}

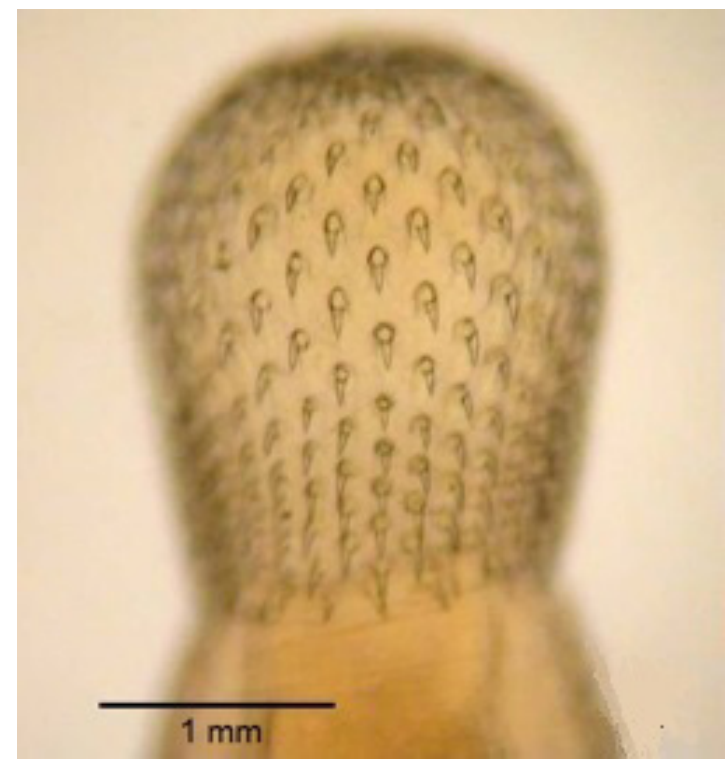

Figure 4. Proboscis morphology of Lueheia inscripta (100X magnification).

of L. inscripta and its possible intermediary hosts is still limited; however, it is known that transmission of this acanthocephalan occurs through ingestion of infected cockroaches (ACHOLONU, 1976). Lueheia inscripta has been described in Platycichla flavipes (Turdidae), Turdus rufiventris, T. albicollis, T. leucomelas, T. amaurochalinus, and T. fumigatus in Brazil (TRAVASSOS, 1926; CALEGARO-MARQUES \& AMATO, 2010), T. grayi in Nicaragua (SCHMIDT \& NEILAND, 1966), Quiscalus niger (Icteridae) and Anolis cristatellus (Squamata) in Puerto Rico (WHITTAKER et al., 1970; ACHOLONU, 1976), and Leptodactylus fragilis (Anura) and Bufo marinus (Anura) in Mexico (SALGADO-MALDONADO \& CASPETA-MANDUJANO, 2010). This is the novel report of L. inscripta in Turdus falcklandii expanding its distributional range to Chile.

\section{Plagiorhynchus cylindraceus}

The subgenus Plagiorhynchus Lühe, 1911 (Acanthocephala: Plagiorhynchidae) is composed of 12 validated species, amongst them $P$. (P.) crassicollis Villot, 1875; P. (P.) odhneri Lundström, 1942; P. (P.) charadrii Yamaguti, 1939; P. (P.) charadriicola Dollfus, 1953; P. (P.) allisonae Skuballa et al. 2010; P. (P.) menurae Johnston, 1912; P. (P.) cylindraceus Goeze, 1782; P. (P.) lemnisalis
Belopol'skaia, 1959; P. (P.) linearis Westrumb, 1891; P. (P.) paulus, $P$. (P.) spiralis and, $P$. (P.) totani (LISITSYNA, 1992; GOLVAN, 1994; SMALES, 2002; DIMITROVA, 2009). In this study, Plagiorhynchus cylindraceus Goeze, 1782 (Figure 5) was found in $6.7 \%(2 / 30)$ of the birds examined. It is a cosmopolitan internal parasite of birds, mostly passerines, but also infects mammals as paratenic hosts (SMALES, 2002). The life cycle of $P$. cylindraceus has been detailed in SCHMIDT \& OLSEN (1964). The infected definitive host releases fully embryonated eggs through its feces, which are ingested by isopod intermediate hosts. The parasite increases its size and develops its organs in the intermediate host until it become infective. When the isopod is ingested by a bird, the parasite attaches itself to its gut wall. It was apparently introduced from Europe to North America, South America, Australia, New Zealand, Asia, and Africa (JONES, 1928; SCHMIDT \& KUNTZ, 1966; AMIN et al., 1999; SMALES, 2002; SKUBALLA et al., 2010; VALENTE et al., 2014).

Plagiorhyinchus cylindraceus has been found in bird and mammal of various families: Sturnidae in Argentina (VALENTE et al., 2014), Scolopacidae in South Africa (AMIN et al., 1999), Procyonidae and Scolopacidae in Canada (CHING et al., 2000; DIDYK et al., 2007), Picidae, Mimidae, Turdidae, Emberizidae, Passerellidae, Anatidae, Phasianidae, Corvidae, Sturnidae, Icteridae, Didelphidae, and Soricidae in the United States (VAN CLEAVE, 1918; JONES, 1928; CUVILLIER, 1934; VAN CLEAVE, 1942; CHANDLER \& RAUSCH, 1949; HUNTER \& QUAY, 1953; SCHMIDT \& OLSEN, 1964; ELTZROTH et al., 1980; MCDONALD, 1988; COADY \& NICKOL, 2000; CARLETON et al., 2012; RICHARDSON, 2013), Strigiformes in Spain (FERRER et al., 2004), Erinaceidae in Czech Republic (PFÄFFLE et al., 2014), Turdidae and Sturnidae in Bulgaria (DIMITROVA et al., 2000), Sturnidae in Ukraine (LISITSYNA, 2010), Erinaceidae in United Kingdom and Germany (SKUBALLA et al., 2010), Turdidae in Poland (RZĄD et al., 2014), Charadriidae, Rallidae, Turdidae, Sturnidae, Corvidae, Monarchidae, Artamidae, Threskiornithidae, Peramelidae, Muridae, Canidae, Macropodidae, Dasyuridae, and Potoroidae in Australia (EDMONDS, 1989; SMALES, 2002), Erinaceidae in New Zealand (SKUBALLA et al., 2010), and Leiothrichidae, Turdidae, and Muscicapidae in Taiwan (SCHMIDT \& KUNTZ, 1966). Infections in small mammals such as shrews are apparently dead ends since the parasites do not mature and passerines such as thrushes are unlikely to ingest these mammals. This is the first time that $P$. cylindraceus is reported in a native species of South America ( $T$. falcklandii) and expands its range to Chile. 


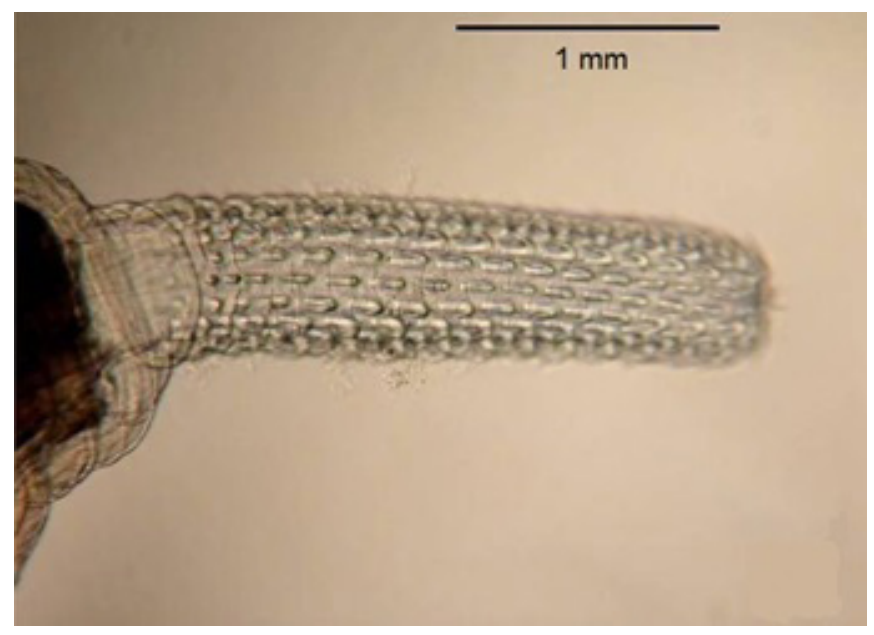

Figure 5. Proboscis morphology of Plagiorhynchus cilyndraceus (100X magnification).

\section{Cestoda}

\section{Wardium sp.}

Wardium sp. sensu Mayhew, 1925 (Cestoda: Hymenolepididae) (Figure 6 and 7) was identified in 20\% (6/30) of the birds examined. Wardium is a cosmopolitan genus of cestodes found mostly in shorebirds (Charadriiformes) but also in birds from the orders Podicipediformes Lariformes, Anseriformes, and Passeriformes (MCDONALD, 1969; BONDARENKO \& KONTRIMAVICHUS, 1978; BONDARENKO, 1997). In South America, few species have been described: Wardium fernandensis in Turdus rufiventris from Brazil (CALEGARO-MARQUES \& AMATO, 2010), W. neotropicale in Himantopus melanurus (Charadriidae) from Paraguay (DEBLOCK \& VAUCHER, 1997), W. paucispinosum in Larus maculipennis (Laridae), and W. semiductilis in L. maculipennis and Larus dominicanus from Argentina (LABRIOLA \& SURIANO, 2000). This is the first time that the genus Wardium is recorded in T. falckandii and Chile.

\section{Dilepis undula}

The genus Dilepis Weinland, 1858 is composed of only two species, D. brachyarthra and D. undula (JAMES \& LLEWELLYN, 1967). Dilepis undula Schrank, 1788 (Cyclophyllidea: Dilepididae) (Figure 8$)$ was observed in a single thrush (1/30) examined. Dilepis undula) is a cosmopolitan cestode that parasitizes the small intestine of passerine birds and mammals (HAUKISALMI, 2015). Its life cycle includes earthworms as intermediate hosts (RYSAVÝ, 1973). Dilepis undula parasitizes different species of the genus Turdus, T. rufiventris in Brazil (CALEGARO-MARQUES \& AMATO, 2010), T. pilaris in Ukraine, Finland, Germany, and United Kingdom (GÄSSLEIN, 1954; JENNINGS \& SOULSBY, 1957; METTRICK, 1958; RAITIS, 1968; ŚWIDERSKI et al., 2000), T. merula in Ukraine, Czech Republic, United Kingdom, Poland, Israel, Spain, United States, Bulgaria, Russia, and New Zealand

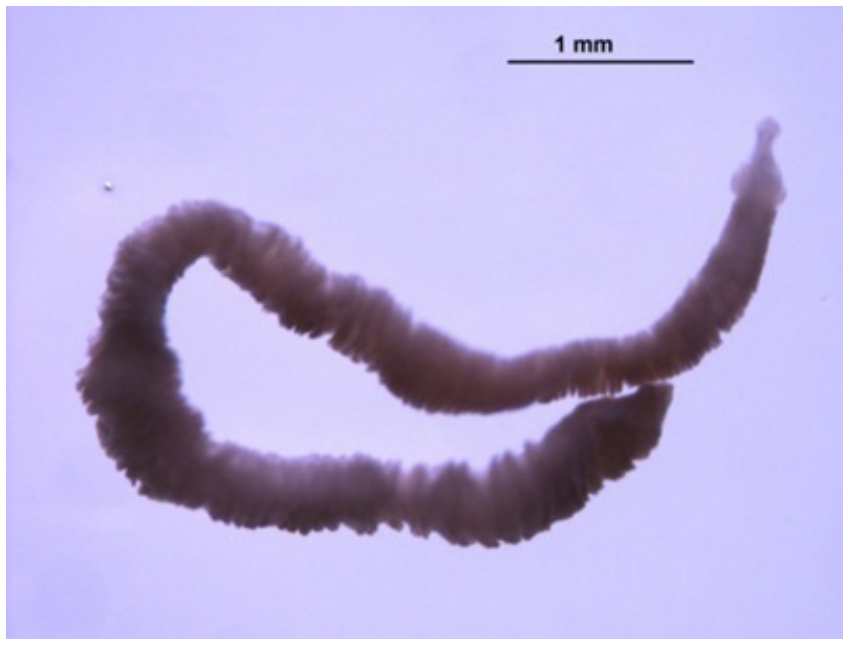

Figure 6. Wardium sp. Specimen (200X magnification).

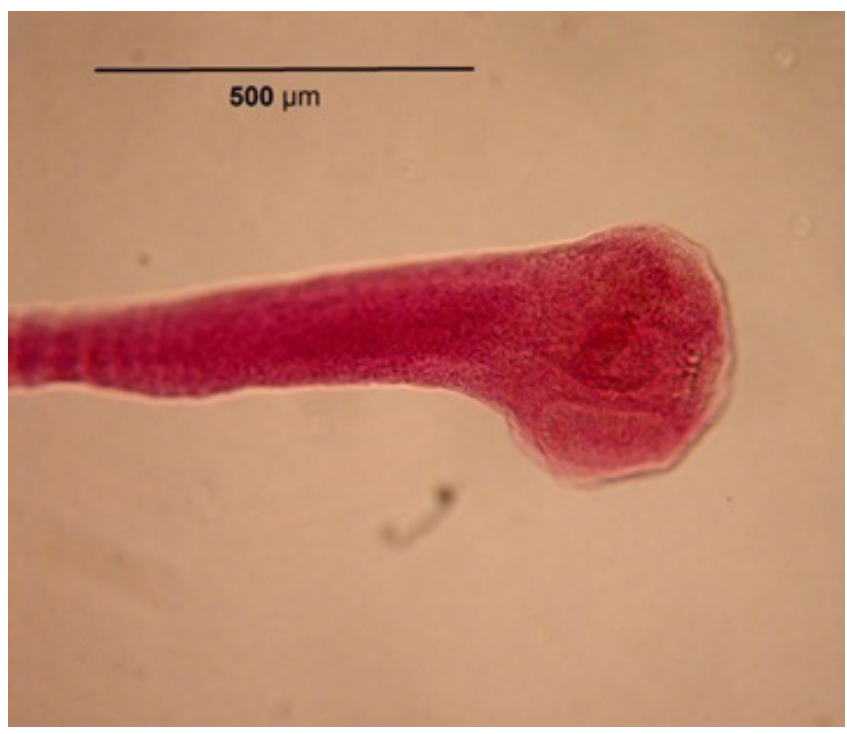

Figure 7. Scolex morphology of Wardium sp. (400X magnification).

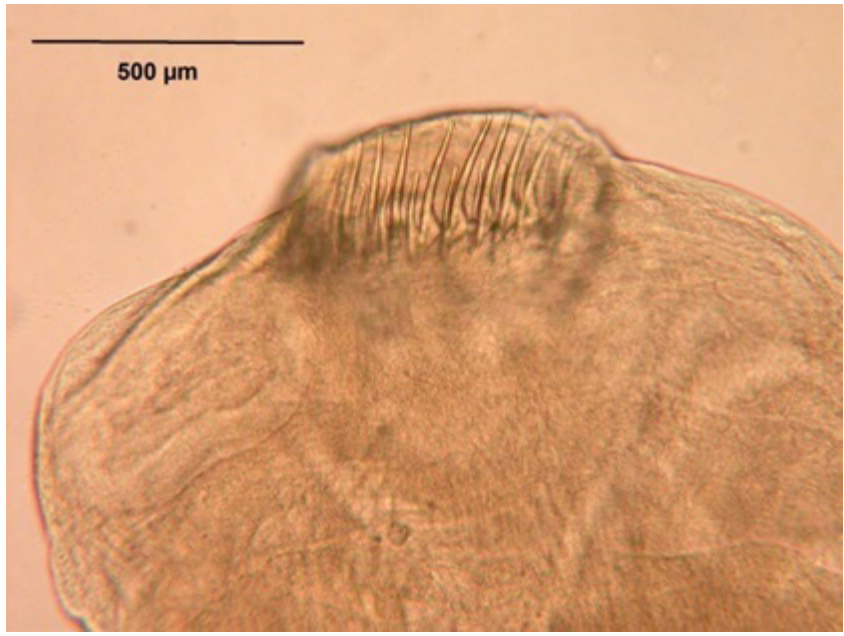

Figure 8. Rostellum of Dilepis undula (200X magnification). 
(DAVIES, 1938; GÄSSLEIN, 1954; PASPALEV \& PASPALEVA, 1965; TARAZONA, 1974; WEEKES, 1982; SCHMIDT et al., 1986; ŚWIDERSKI et al., 2004; PETKEVIČIŪTĖ et al., 2006; OKULEWICZ \& SITKO, 2012; RZĄD et al., 2014), T. iliacus in Finland (RAITIS, 1968), T. philomelos in Finland, Spain, United Kingdom, Germany, and New Zealand (DAVIES, 1938; GÄSSLEIN, 1954; TARAZONA, 1974; WEEKES, 1982; HAUKISALMI, 2015), T. viscivorus in Finland and the United Kingdom (METTRICK, 1958; PASPALEV \& PASPALEVA, 1965; TARAZONA, 1974; HAUKISALMI, 2015), T. migratorius in the United States and Canada (SLATER, 1967; CHING, 1993), and T. grayi in Nicaragua (SCHMIDT \& NEILAND, 1971). This is the first record of $D$. undula in T. falcklandii expanding its range to Chile. Sitko \& Zaleśny (2014) indicated that D. undula is a dominant parasite species of $T$. merula in urban settings but is less prevalent in the individuals living in forests. This could also be the case for T. falcklandii, which possesses urban and natural populations in Chile.

\section{Trematoda}

Only a single Zonorchis sp. sensu Travassos, 1944 (Trematoda: Dicrocoeliidae) was collected from the thrushes examined. Zonorchis species are usually found in the gall bladder and bile ducts of birds and mammals all over the world, but predominantly in tropical countries of Central and South America (TRAVASSOS, 1945; THATCHER \& PORTER, 1968). Zonorchis goliath has been found in Didelphis marsupialis (Didelphidae) and Saguinus geoffroyi (Callitrichidae); Z. confusus in Procnias nudicollis (Cotingidae) and Zonorchis spp. in Didelphis albiventris (Didelphidae) from Brazil (TRAVASSOS, 1945; TRAVASSOS et al., 1969; MELO, 2009; RAMOS et al., 2016); Z. microrchis in Psophia viridis (Gruiformes), Z. costaricensis in Gymnostinops montezuma (Icteridae) and Z. macroovarus in Pteroglossus torquatus (Ramphastidae) from Costa Rica (BRENES \& JIMÉNEZ-QUIRÓS, 1959; JIMÉNEZ-QUIRÓS \& ARROYO, 1960); Z. allentoshi in Caluromys derbianus (Didelphidae) and Z. goliath in S. geoffroyi and Aotus trivirgatus (Aotidae) from Panamá (THATCHER \& PORTER, 1968; LAMOTHE-ARGUMEDO et al., 1997); Z. delectans in Gymnopithys leucaspis (Thamnophilidae), Myrmeciza hyperythra (Thamnophilidae), Schistocichla leucostigma (Thamnophilidae), Cymbilaimus lineatus (Thamnophilidae), Hypocnemis cantator (Thamnophilidae), Myrmoborus myotherinus (Thamnophilidae), M. axillaris (Thamnophilidae), M. hauxwelli, M. ornate, M. schisticolor, Phlegopsis erythroptera (Thamnophilidae), P. nigromaculata, Thamnomanes ardesiacus (Thamnophilidae) and Th. caesius, and $Z$. meyeri in Laterallus jamaicensis (Rallidae) in Ecuador (VERCAMMEN-GRANDJEAN, 1966; TALLMAN \& TALLMAN, 1994). The only record of Zonorchis in the Turdus genus is Zonorchis petiolatus in the Czech Republic (SITKO \& ZALEŚNY, 2014). This is the first time that a member of the Zonorchis genus is reported in a free-ranging species in Chile.

\section{Acknowledgements}

The authors would like to thank Catalina Ramírez and María Ignacia Bueno for their assistance during sample collection. Thank to Project FONDECYT 1170972.

\section{References}

Acholonu AD. Helminth fauna of saurians from Puerto Rico with observations on the life cycle of Lueheia inscripta (Westrumb, 1821) and description of Allopharynx puertoricensis sp. n. Proc Helminthol Soc Wash 1976; 43(2): 106-116.

Amin OM, Canaris AG, Kinsella JM. A taxonomic reconsideration of the genus Plagiorhynchus s. lat. (Acanthocephala: Plagiorhynchidae), with descriptions of South African Plagiorhynchus (Prosthorhynchus) cylindraceus from shore birds and $P .(P$.$) malayensis, and a key to the species of the$ subgenus Prosthorhynchus. J Helminthol Soc Wash 1999; 66(2): 123-132.

Barreto M, Burbano ME, Proctor HC, Mironov SV, Wauthy G. Feather mites (Acariformes: Psoroptidia) from Colombia: Preliminary list with new records. Zootaxa 2012; 3516(1): 1-68. http://dx.doi.org/10.11646/ zootaxa.3516.1.1.

Bondarenko SK, Kontrimavichus VL. Life-cycle of the cestode Wardium calumnacantha (Schmidt, 1963) comb. n. (Hymenolepididae) from common snipe, Gallinago gallinago (L.). Folia Parasitol (Praha) 1978; 25(1): 35-39. PMid:640521.

Bondarenko SK. The life cycle of the Wardium fryei (Cestoda: hymenolepididae). Parazitologiia 1997; 31(2): 142-156.

Brenes RR, Jiménez-Quirós O. Helmintos de la República de Costa Rica XII. Zonorchis costarricensis n. sp. (Trematoda, Dicrocoeliidae) parásito de las vías biliares de Gymnostinops montezuma (Icteridae). Rev Biol Trop 1959; 7(1): 125-129.

Burmeister HCC. Mallophaga. In: Burmeister HCC. Handbuch der Entomologie. Berlin: Verlag von G. Reimer; 1838. p. 418-443.

Bush AO, Lafferty KD, Lotz JM, Shostak AW. Parasitology meets ecology on its own terms: margolis et al. revisited. J Parasitol 1997; 83(4): 575 583. http://dx.doi.org/10.2307/3284227. PMid:9267395.

Calegaro-Marques C, Amato SB. Parasites as secret files of the trophic interactions of hosts: the case of the rufous-bellied thrush. Rev Mex Biodivers 2010; 81(3): 801-811.

Carleton RE, Mertins JW, Yabsley MJ. Parasites and pathogens of eastern bluebirds (Sialia sialis): a field survey of a population nesting within a grass-dominated agricultural habitat in Georgia, USA, with a review of previous records. Comp Parasitol 2012; 79(1): 30-43. http://dx.doi. org/10.1654/4493.1.

Carriker MA. Neotropical Mallophaga (Insecta) miscellany. Rev Bras Biol 1963; 23(3): 293-316.

Castro DC, Cicchino A. Contribucion al conocimiento de los malofagos argentinos III. Sobre algunos Menoponidae de la avifauna bonaerense: Menacanthus eurysternus (Burmeister) y Menacanthus pici (Denny) (Insecta: Mallophaga). Rev Soc Entomol Argent 1978; 37(1-4): 78-83.

Castro DC, Cicchino A. Algunas Menoponidae (Insecta-Phthiraptera) de aves bonaerenses. Rev Asoc Cienc Nat Litor St Tome 1996; 27(2): 137-140.

Chandler AC, Rausch RL. A contribution to the study of certain avian strigeids (Trematoda). J Parasitol 1949; 34(3): 207-210. http://dx.doi. org/10.2307/3273266. PMid:18867395. 
Chester S. A wildlife guide to Chile: Continental Chile, Chilean Antarctica, Easter Island, Juan Fernandez Archipelago. New Jersey: Princeton University Press; 2008.

Ching HL, Leighton BJ, Stephen C. Intestinal parasites of raccoons (Procyon lotor) from southwest British Columbia. Can J Vet Res 2000; 64(2): 107-111. PMid:10805249.

Ching HL. Helminths of varied thrushes, Ixoreus naevius, and robins Turdus migratorius, from British Columbia. J Helminthol Soc Wash 1993; 60(2): 239-242.

Cicchino A, Castro DDC. Ischnocera. In: Morrone JJ, Coscarón S. Biodiversidad de Artrópodos argentinos. San Miguel de Tucumán: Editorial INSUE - UNT; 1998. p. 104-124.

Cicchino A, Castro DDC. Revisión preliminar de las especies del género Brueelia Kéler, 1936 (Phthiraptera, Philopteridae) parásitas de Icterinae (Aves, Passeriformes, Fringillidae). Graellsia 1996; 52(0): 3-30. http:// dx.doi.org/10.3989/graellsia.1996.v52.i0.373.

Cicchino A, González-Acuña D. A new species of Brueelia Kéler (Phthiraptera: Philopteridae) parasitic on the common diuca-finch, Diuca diuca diuca (Aves: Emberizidae) in Chile. Neotrop Entomol 2009; 38(4): 504-507. http://dx.doi.org/10.1590/S1519-566X2009000400011. PMid: 19768270

Cicchino A. Adición a la revisión de las especies del género Brueelia Kéler, 1936 (Phthiraptera: Philopteridae) parásitas de Icterinae. Las especies parásitas del género Agelaius Vieillot, 1816 (Aves: Passeriformes: Fringillidae). Bol Mus Nac Hist Nat Paraguai 2004; 15(1-2): 66-81.

Cicchino A. Contribucion al conocimiento de los malofagos argentinos. XIX. Cuatro nuevas especies del genero Brueelia Keler 1936 (Philoptheridae) parasitas de especies de Turdus Linne 1758 (Aves, Passeriformes, Muscicapidae, Turdinae). Rev Soc Entomol Argent 1986; 44(1): 91-102.

Cicchino A. Contribución al conocimiento de los malófagos argentinos XII. Cuatro nuevas especies del género Brueelia Kéler, 1936 (Mallophaga, Philopteridae) parásitas de Emberizidae y Tersinidae (Aves, Passeriformes). Rev Soc Entomol Argent 1982; 41(1-4): 279-288.

Cicchino A. Contribución al conocimiento de los malófagos argentinos XX. Primera edición a la adicion preliminar de las especies del género Brueelia Keler, 1936 (Mallophaga: Philopteridae) parasitas de Icterinae (Aves: Passeriformes: Emberizidae). Spheniscus 1990; 8: 21-26.

Cicchino A. Especies nuevas o poco conocidas del género Brueelia Keler, 1963 (Mallophaga: Philopteridae) parasitas de Passeriformes, Piciformes y Trogoniformes (aves) americanos. Rev Soc Entomol Argent 1983; 42(14): 283-303.

Cicchino A. Una nueva especie del género Brueelia Keler 1936 (Phthiraptera: Philopteridae), parásita de Turdus amaurochalinus Cabanis (Passeriformes: Muscicapidae). Spheniscus 1987; 5: 35-36.

Cicchino A. Una nueva especie del género Brueelia Keler, 1936 (Mallophaga, Philopteridae) parásita de Leuconerpes candidus (Otto) (Aves, Picidae) en Paraguay. Rev Soc Entomol Argent 1979; 38(1-4): 91-96.

Cicchino AC, González-Acuña D. Two new species of Brueelia (Phthiraptera: Philopteridas sl) parasitic on two species of Phrygilus (Aves: Emberizidae) from Chile. Neotrop Entomol 2008; 37(3): 301-304. http://dx.doi. org/10.1590/S1519-566X2008000300009. PMid:18641901.

Cicchino AC. Tyranniphilopterus polioptilus new species (Phthiraptera: Ischnocera: Philopteridae) parasitic on the masked gnatcatcher, Polioptila dumicola (Passeriformes, Polioptilidae) in Argentina. Zootaxa 2007; 1547(1): 43-50. http://dx.doi.org/10.11646/zootaxa.1547.1.4.
Clayton DH, Gregory RD, Price RD. Comparative ecology of Neotropical bird lice (Insecta: phthiraptera). J Anim Ecol 1992; 61(3): 781-795. http:// dx.doi.org/10.2307/5631.

Coady NR, Nickol BB. Assessment of parenteral Plagiorhynchus cylindraceus (Acanthocephala) infections in shrews. Comp Parasitol 2000; 67(1): 32-39.

Cunha HL, Bergmann FB, dos Santos PRS, Krüger RF, Graciolli G. Community of arthropod ectoparasites of two species of Turdus Linnaeus, 1758 (Passeriformes: Turdidae) in southern Rio Grande do Sul, Brazil. Parasitol Res 2013; 112(2): 621-628. http://dx.doi.org/10.1007/s00436012-3174-5. PMid:23093206.

Cuvillier E. New bird hosts for the acanthocephalid Plagiorhynchus formosus (Echinorhynchidae). Proc Helminthol Soc Wash 1934; 1(2): 63.

Davies TI. The Anatomy of Dilepis undula (Schrank, 1788). Proc Zool Soc Lond 1938; 105(3): 717-722. http://dx.doi.org/10.1111/j.1096-3642.1935. tb01689.x.

Deblock S, Vaucher C. Microsomacanthus kaulobatroni n. sp. et Wardium neotropicale n. sp. parasites d' Himantopus melanurus du Paraguay. Syst Parasitol 1997; 37(2): 127-138. http://dx.doi.org/10.1023/A:1005702232654.

Didyk AS, Canaris AG, Kinsella JM. Intestinal helminths of the spotted sandpiper, Actitis macularius (L.), during fall migration in New Brunswick, Canada, with a checklist of helminths reported from this host. Comp Parasitol 2007; 74(2): 359-363. http://dx.doi.org/10.1654/4280.1.

Dimitrova Z, Georgiev BB, Genov T. Review of the avian acanthocephalans from Bulgaria. Acta Zool Bulg 2000; 52(3): 3-22.

Dimitrova Z. Acanthocephalans of the nominotypical subgenus of Plagiorhynchus (Plagiorhynchidae) from charadriiform birds in the collection of the Natural History Museum, London, with a key to the species of the subgenus. ZooKeys 2009; 6: 75-90. http://dx.doi. org/10.3897/zookeys.6.94.

Edmonds SJ. A list of Australian Acanthocephala and their hosts. Rec South Aust Mus 1989; 23(2): 127-133.

Eltzroth EK, Cromack AA, Thompson-Cowley LL. Endoparasitism in western bluebirds of Oregon. Sialia 1980; 2: 67-70.

Enout AM, Lobato DN, Azevedo CS, Antonini Y. Parasitismo por malófagos (Insecta) e ácaros (Acari) em Turdus leucomelas (Aves) nas estaçóes reprodutiva e de muda de penas no Parque Estadual do Rio Preto, Minas Gerais, Brasil. Zoologia 2009; 26(3): 534-540. http://dx.doi. org/10.1590/S1984-46702009000300017.

Enout AM, Lobato DN, Diniz FC, Antonini Y. Chewing lice (Insecta, Phthiraptera) and feather mites (Acari, Astigmata) associated with birds of the Cerrado in Central Brazil. Parasitol Res 2012; 111(4): 1731-1742. http://dx.doi.org/10.1007/s00436-012-3016-5. PMid:22773045.

Fairn ER, Hornsby MA, Galloway TD, Barber CA. Ectoparasites of nestling European starlings (Sturnus vulgaris) from a nest box colony in Nova Scotia, Canada. J Acad Entomol Soc 2014; 10: 19-22.

Ferrer D, Molina R, Castella J, Kinsella JM. Parasitic helminths in the digestive tract of six species of owls (Strigiformes) in Spain. Vet J 2004; 167(2): 181-185. http://dx.doi.org/10.1016/S1090-0233(03)00103-5. PMid:14975393.

Galloway TD, Proctor HC, Mironov SV. Chewing Lice (Insecta: Phthiraptera: Amblycera, Ischnocera) and Feather Mites (Acari: Astigmatina: Analgoidea, Pterolichoidea): Ectosymbionts of Grassland Birds in Canada. In: Cárcamo HA, Giberson DJ. Arthropods of Canadian grasslands. Ottawa: Biological Survey of Canada; 2014. p. 139-188. (vol. 3, Part 1). 
Gässlein H. Die cestoden der Vertebraten aus der Umgebung von Erlangen. Parasitol Res 1954; 16(5): 443-468. PMid:14360337.

Golvan YJ. Nomenclature of the Acanthocephala. Res Rev Parasitol 1994; 54(3): 135-205.

Gómez-Puerta LA, Cribillero NG. Contribución al conocimiento de los malófagos (Phthiraptera, Amblycera, Ischnocera) de aves peruanas: Parte 1. Rev Peru Biol2015; 22(3): 341-346. http://dx.doi.org/10.15381/rpb. v22i3.11441.

González-Acuña D, Venzal JM, Keirans JE, Robbins RG, Ippi S, Guglielmone AA. New host and locality records for the Ixodes auritulus (Acari: Ixodidae) species group, with a review of host relationships and distribution in the Neotropical Zoogeographic Region. Exp Appl Acarol 2005; 37(1-2): 147-156. http://dx.doi.org/10.1007/s10493-005-8434-y. PMid:16180081.

González-Acuña D, Vergara F, Moreno L, Barrientos C, Ardiles K, Cicchino A. Lice (Insecta: Phthiraptera) from species of the families Furnariidae, Tyrannidae, Turdidae and Icteridae (Aves: Passeriformes) from Chile. Gayana (Concepc) 2006; 70(2): 210-219. http://dx.doi.org/10.4067/ S0717-65382006000200008.

Hastriter MW, Schlatter RP. Revision of the fleas in the subgenus Dasypsyllus (Neornipsyllus)(Siphonaptera: ceratophyllidae). Ann Carnegie Mus 2006; 75(4): 247-257. http://dx.doi.org/10.2992/0097-4463(2006)75[247:RO TFIT]2.0.CO;2.

Haukisalmi V. Checklist of tapeworms (Platyhelminthes, Cestoda) of vertebrates in Finland. ZooKeys 2015; 533(533): 1-61. http://dx.doi. org/10.3897/zookeys.533.6538. PMid:26668540.

Hernandes FA, Pedroso LG, Oniki-Willis Y. Five new feather mites of the subfamily Pterodectinae (Acariformes: Astigmata: Proctophyllodidae) from passerines and hummingbirds (Aves) of Brazil. Zootaxa 2016; 4161(3): 301-328. http://dx.doi.org/10.11646/zootaxa.4161.3.1. PMid:27615933.

Hunter WS, Quay TL. An ecological study of the helminth fauna of Macgillivray's seaside sparrow, Ammospiza maritima macgillivraii (Audubon). Am Midl Nat 1953; 50(2): 407-413. http://dx.doi.org/10.2307/2422099.

James BL, Llewellyn LC. A quantitative analysis of helminth infestation in some passerine birds found dead on the Island of Skomer. J Helminthol 1967; 41(1): 19-44. http://dx.doi.org/10.1017/S0022149X00021337.

Jaramillo A. Aves de Chile. Barcelona: Lynx Ediciones; 2005.

Jennings AR, Soulsby EJL. Diseases of wild birds, fourth report. Bird Study 1957; 4(4): 216-220. http://dx.doi.org/10.1080/00063655709475893.

Jiménez-Quirós O, Arroyo G. Helmintos de la República de Costa Rica. XIV. Redescripción de Lutztrema obliquum Travassos, 1941, y descripción de Zonorchis macroovaricus n. sp. Rev Biol Trop 1960; 8(1): 53-61.

Jones M. An acanthocephalid, Plagiorhynchus formosus, from the chicken and the robin. J Agric Res 1928; 36(9): 773-775.

Khalil LF, Jones A, Bray RA. Keys to the cestode parasites of vertebrates. Wallingford: CAB International; 1994.

Kinsella JM, Forrester DJ. Helminths of the Florida Duck, Anas platyrhynchos fulvigula. Proc Helminthol Soc Wash 1972; 39(2): 173-176.

Krantz GW. A manual of acarology. 2nd ed. Corvallis: Oregon State University Book Stores; 1978.

Kuabara KM, Valim MP. New records of chewing lice (Insecta, Phthiraptera) from Brazilian birds (Aves) collected by Helmut Sick (1910-1991). Rev Bras Entomol 2017; 61(2): 146-161. http://dx.doi.org/10.1016/j. rbe.2016.12.006.
Labriola JB, Suriano DM. Wardium paucispinosum sp. n.(Eucestoda: Hymenolepididae), parasite of Larus maculipennis (Aves: Laridae) in Mar del Plata, Argentina; with comments on Wardium semiductilis (Szidat, 1964) comb. n. Folia Parasitol (Praha) 2000; 47(3): 205-210. http:// dx.doi.org/10.14411/fp.2000.038. PMid:11104148.

Lamothe-Argumedo R, García-Prieto L, Osorio-Sarabia D, Pérez Ponce de Léon G. Catálogo de la colección nacional de helmintos. Universidad Nacional Autónoma de México; 1997.

Lindell CA, Gavin TA, Price RD, Sanders AL. Chewing louse distributions on two Neotropical thrush species. Comp Parasitol 2002; 69(2): $212-$ 217. http://dx.doi.org/10.1654/1525-2647(2002)069[0212:CLDOT $\mathrm{N}] 2.0 . \mathrm{CO} ; 2$.

Lisitsyna O. Morphological variability of Plagiorhynchus (Prosthorhynchus) cylindraceus (Acanthocephala, Plagiorhynchidae) and its importance in assessment of taxonomy structure of the subgenus. Vestn Zool 2010; 44(6): e35-e44. http://dx.doi.org/10.2478/v10058-010-0035-5.

Lisitsyna O. Spiny-headed worms of the genus Plagiorhynchus (Acanthocephala, Plagiorhynchidae) of the Ukrainian fauna, with a description of a new species. Vestn Zool 1992; 3: 3-8.

Martínez D, González G. Las aves de Chile: nueva guía de campo. Santiago: Ediciones del Naturalista; 2004.

Martinů J, Sychra O, Literák I, Čapek M, Gustafsson DL, Štefka J. Host generalists and specialists emerging side by side: an analysis of evolutionary patterns in the cosmopolitan chewing louse genus Menacanthus. Int J Parasitol2015; 45(1): 63-73. http://dx.doi.org/10.1016/j.ijpara.2014.09.001. PMid:25311782.

McDonald ME. Catalogue of helminths of waterfowl (Anatidae). Washington: Bureau of Sport Fisheries and Wildlife; 1969.

McDonald ME. Key to Acanthocephala reported in waterfowl. Washington: Fish and Wildlife Service; 1988.

Melo DSV. Identificação e controle de trematódeos de vesícula biliar em Callitrix penicillata naturalmente parasitados [dissertação]. Brasília: Universidade de Brasília; 2009.

Mettrick DF. Helminth parasites of Hertfordshire birds II - Cestoda. J Helminthol 1958; 32(3): 159-194. http://dx.doi.org/10.1017/ S0022149X00019568. PMid:13587969.

Mironov SV, González-Acuña D. A new species of the feather mite genus Tyrannidectes Mironov, 2008 (Acariformes: Proctophyllodidae) from tapaculos (Passeriformes: Rhinocryptidae) in Chile. Acta Parasitol 2015; 60(4): 743-748. http://dx.doi.org/10.1515/ap-2015-0106. PMid:26408600.

Mironov SV, González-Acuña D. New feather mites of the subfamily Pterodectinae (Acariformes: Proctophyllodidae) from passerines (Aves: Passeriformes) from Chile and Cuba. Zootaxa 2011; 3057(1): 1-48. http://dx.doi.org/10.11646/zootaxa.3057.1.1.

Mironov SV, Literak I, Čapek M. New feather mites of the subfamily Pterodectinae (Acari: Astigmata: Proctophyllodidae) from passerines (Aves: Passeriformes) in Mato Grosso do Sul, Brazil. Zootaxa 2008; 1947(1): 1-38. http://dx.doi.org/10.11646/zootaxa.1947.1.1.

Nelder MP, Reeves WK. Ectoparasites of road-killed vertebrates in northwestern South Carolina, USA. Vet Parasitol 2005; 129(3-4): 313 322. http://dx.doi.org/10.1016/j.vetpar.2004.02.029. PMid:15845287.

Nybelin O. Säugetier und Vogelcestoden von Juan Fernandez. Zool Soc Lond 1929; 27: 493-523. 
Okulewicz A, Sitko J. Parasitic helminthes: probable cause of death of birds. Helminthologia 2012; 49(4): 241-246. http://dx.doi.org/10.2478/ s11687-012-0045-7.

Parra-Henao G, Alarcón EP, López G, Monroy R, Diber M, Jaramillo GE. Detection of ectoparasites in wild birds evaluated in Medellin (Colombia). Rev Colomb Cienc Pecu 2011; 24(1): 29-37.

Paspalev G, Paspaleva A. Studies on the helminth fauna of wild birds from the Petrtch and Gotse Deltchev Regions. III. Species composition and distribution of Cestoda. Izvestiya na Zoologicheskiya Instituts Muzey 1965; 19: 135-147.

Petkevičiūtė R, Binkienė R, Komisarovas J. Diversity of Dilepididae (Cestoda: Cyclophyllidea) revealed by cytogenetic analysis. J Helminthol 2006; 80(1): 59-63. http://dx.doi.org/10.1079/JOH2005319. PMid:16469174.

Pfäffle M, Černá Bolfíková B, Hulva P, Petney T. Different parasite faunas in sympatric populations of sister hedgehog species in a secondary contact zone. PLoS One 2014; 9(12): e114030. http://dx.doi.org/10.1371/journal. pone.0114030. PMid:25469872.

Price RD, Emerson KC. The Menacanthus (Mallophaga: Menoponidae) of the Piciformes (Aves). Ann Entomol Soc Am 1975; 68(5): 779-785. http://dx.doi.org/10.1093/aesa/68.5.779.

Price RD, Hellenthal RA, Palma RL. World checklist of chewing lice with host associations and keys to families and genera. Illinois: Illinois Natural History Survey Special Publication; 2003.

Price RD. The Menacanthus eurysternus complex (Mallophaga: Menoponidae) of the Passeriformes and Piciformes (Aves). Ann Entomol Soc Am 1975; 68(4): 617-622. http://dx.doi.org/10.1093/aesa/68.4.617.

Pritchard MH, Kruse GO. The collection and preservation of animal parasites. Lincoln: University of Nebraska Press; 1982.

Raitis T. Turun yliopiston eläintieteen laitoksen loiskokoelman pohjoismainen osa (Nordiska delen av den parasitsamling som ägs av zoologiska institutet vid Turun yliopisto). Helsinki: Finska Vetenskaps-Societetens Parasitologiska Institut; 1968. p. 20-25. (Tiedoksianto - Information; vol. 8).

Ramos D, Santos A, Freitas LC, Correa S, Kempe G, Morgado T, et al. Endoparasites of wild animals from three biomes in the State of Mato Grosso, Brazil. Arq Bras Med Vet Zootec 2016; 68(3): 571-578. http:// dx.doi.org/10.1590/1678-4162-8157.

Richardson DJ. Helminth parasites of the raccoon (Procyon lotor), Virginia opossum (Didelphis virginiana), and striped skunk (Mephitis mephitis) from Keith County, Nebraska. Trans Nebr Acad Sci 2013; 33: 35-38.

Rozzi R, Armesto J, Correa A, Torres-Mura J, Sallaberry M. Avifauna de bosques primarios templados en islas deshabitadas del Archipiélago de Chiloé, Chile. Rev Chil Hist Nat 1996; 69: 125-139.

Rysavý B. Eiseniella tetraedra (Savigny) (Oligochaeta), a new intermediate host of the cestode Dilepis undula (Schrank, 1782). Folia Parasitol (Praha) 1973; 20(1): 16. PMid:4804971.

Rząd I, Sitko J, Sałamatin R, Wysocki D. Helminth community structure study on urban and forest blackbird (Turdus merula L.) populations in relation to seasonal bird migration on the south Baltic Sea coast (NW Poland). Helminthologia 2014; 51(2): 117-129. http://dx.doi.org/10.2478/ s11687-014-0219-6.

Salgado-Maldonado G, Caspeta-Mandujano JM. Lueheia inscripta (Westrumb, 1821)(Acanthocephala: Plagiorhynchidae) in anurans (Leptodactylidae: Bufonidae) from Mexico. Parasite 2010; 17(2): 161165. http://dx.doi.org/10.1051/parasite/2010172161. PMid:20597444.
Sari EH, Klompen H, Parker PG. Tracking the origins of lice, haemosporidian parasites and feather mites of the Galápagos flycatcher (Myiarchus magnirostris). J Biogeogr 2013; 40(6): 1082-1093. http:// dx.doi.org/10.1111/jbi.12059.

Schmidt GD, Greenberg Z, Wertheim G. Raillietina (Raillietina) alectori sp. n. and other avian cestodes from Israel and Sinai. Bull Mus Natl Hist Nat 1986; 8: 101-109.

Schmidt GD, Kuntz RE. New and little-known Plagiorhynchid Acanthocephala from Taiwan and the Pescadores Islands. J Parasitol 1966; 52(3): 520-527. http://dx.doi.org/10.2307/3276322. PMid:5944663.

Schmidt GD, Neiland KA. Helminth fauna of Nicaragua. III. Some Acanthocephala of birds, including three new species of Centrorhynchus. J Parasitol 1966; 52(4): 739-745. http://dx.doi.org/10.2307/3276447. PMid:5969117.

Schmidt GD, Neiland KA. Helminth fauna of Nicaragua: IV. Sacciuterina mathevossiani sp. nov. (Dilepididae), and other cestodes of birds. Parasitology 1971; 62(1): 145-149. http://dx.doi.org/10.1017/S0031182000071353. PMid:4256987.

Schmidt GD, Olsen OW. Life cycle and development of Prosthorhynchus formosus (Van Cleave, 1918) Travassos, 1926, an acanthocephalan parasite of birds. J Parasitol 1964; 50(6): 721-730. http://dx.doi. org/10.2307/3276191. PMid:14244802.

Sitko J, Zaleśny G. The effect of urbanization on helminth communities in the Eurasian blackbird (Turdus merula L.) from the eastern part of the Czech Republic. J Helminthol 2014; 88(1): 97-104. http://dx.doi. org/10.1017/S0022149X12000818. PMid:23232073.

Skuballa J, Taraschewski H, Petney TN, Pfäffle M, Smales LR. The avian acanthocephalan Plagiorhynchus cylindraceus (Palaeacanthocephala) parasitizing the European hedgehog (Erinaceus europaeus) in Europe and New Zealand. Parasitol Res 2010; 106(2): 431-437. http://dx.doi. org/10.1007/s00436-009-1681-9. PMid:19937258.

Slater RL. Helminths of the robin, Turdus migratorius Ridgway, from Northern Colorado. Am Midl Nat 1967; 77(1): 190-199. http://dx.doi. org/10.2307/2423438.

Smales LR. Plagiorhynchidae Meyer, 1931 (Acanthocephala) from Australasian birds and mammals, with descriptions of Plagiorhynchus (Plagiorhynchus) menurae (Johnston, 1912) and P.(P.) allisonae n. sp. Syst Parasitol 2002; 51(3): 207-216. http://dx.doi.org/10.1023/A:1014590530850. PMid:11912346.

Świderski Z, Salamatin RV, Grytner-Zięcina B, Kornyushin VV, Conn DB. Electron microscope study on oncospheral envelope morphogenesis in the dilepidid cestode, Dilepis undula (Schrank, 1788). Acta Parasitol 2004; 49(4): 300-308.

Świderski Z, Tkach VV, Salamatin RV. Oncospheral hook morphogenesis in the cestode Dilepis undula (Schrank, 1788) (Cyclophyllidea, Dilepididae). Acta Parasitol 2000; 45(4): 322-331.

Sychra O, Literak I, Napek M, Havlqñek M. Chewing lice (Phthiraptera) from buntings, cardinals and tanagers (Passeriformes: Emberizidae, Cardinalidae, Thraupidae) from Costa Rica, with descriptions of two new species of the genus Myrsidea (Phthiraptera: Menoponidae). Zootaxa 2007; 1631(1): 57-68. http://dx.doi.org/10.11646/zootaxa.1631.1.4.

Tallman EJ, Tallman DA. The trematode fauna of an Amazonian antbird community. Auk 1994; 111(4): 1006-1013. http://dx.doi. org/10.2307/4088836.

Tarazona JM. Helmintos parásitos de vertebrados de vida silvestre de la prov. de Huesca. An Inst N Inv Agrar 1974; 1: 161-166. 
Thatcher VE, Porter JA Jr. Some helminth parasites of Panamanian primates. Trans Am Microsc Soc 1968; 87(2): 186-196. http://dx.doi. org/10.2307/3224439. PMid:4967212.

Travassos L, Freitas JFT, Kohn A. Trematódeos do Brasil. Mem Inst Oswaldo Cruz 1969; 67(1): 1-886. PMid:5397756.

Travassos L. Contribuiçóes para o conhecimento da fauna helminthologica brasileira. XX. Revisão dos Acanthocephalos brasileiros. Parte II. Familia Echinorhynchidae Hamann, 1892, sub-fam. Centrorhynchinae Travassos, 1919. Mem Inst Oswaldo Cruz 1926; 19: 32-125.

Travassos L. Notas sobre Dicrocoeliidae. Mem Inst Oswaldo Cruz 1945; 42(3): 629-633. http://dx.doi.org/10.1590/S0074-02761945000300006. PMid:20983869.

Trouessart EL. Note sur la classification des Analgésiens et diagnoses d'espèces et de genres nouveaux. Bull Soc d'Etud sci d'Angers 1885; 14: 46-89.

Valente R, Ibañez LM, Lorenti E, Fiorini VD, Montalti D, Diaz JI. Helminth parasites of the European starling (Sturnus vulgaris)(Aves, Sturnidae), an invasive bird in Argentina. Parasitol Res 2014; 113(7): 27192724. http://dx.doi.org/10.1007/s00436-014-3928-3. PMid:24804922.

Valim MP, Cicchino AC. A remarkable new genus and a new species of chewing louse (Phthiraptera, Ischnocera, Philopteridae) from Brazil. ZooKeys 2015; 2015(541): 57-70. http://dx.doi.org/10.3897/zookeys.541.6022. PMid:26798280.

Valim MP, Hernandes FA. A systematic review of feather mites of the Pterodectes generic complex (Acari: Proctophyllodidae: Pterodectinae) with redescriptions of species described by Vladimír Černý. Acarina (Mosc) 2010; 18(1): 3-35.
Valim MP, Hernandes FA. Redescriptions of five species of the feather mite genus Pterodectes Robin, 1877 (Acari: Proctophyllodidae: Pterodectinae) with the proposal of a new genus and a new species. Acarina (Mosc) 2008; 16(2): 131-157.

Valim MP, Palma RL. A new species of Brueelia Kéler, 1936 (Phthiraptera: Ischnocera: Philopteridae) from the blue-black grassquit (Aves: Passeriformes: Emberizidae) in Brazil. Zootaxa 2006; 1153(1): 27-32. http://dx.doi. org/10.11646/zootaxa.1153.1.3

Van Cleave HJ. A reconsideration of Plagiorhynchus formosus and observations on Acanthocephala with atypical lemnisci. Trans Am Microsc Soc 1942; 61(2): 206-210. http://dx.doi.org/10.2307/3222848.

Van Cleave HJ. The Acanthocephala of North American birds. Trans Am Microsc Soc 1918; 37(1): 19-47. http://dx.doi.org/10.2307/3221445.

Vercammen-Grandjean PH. Zonorchis meyeri, new species, a parasite of the gall bladder of a rail in the Galápagos Islands (Trematoda: dicrocoeliidae). Proc Calif Acad Sci 1966; 33(4): 65-68.

Weekes PJ. Checklist of helminth parasites of birds in New Zealand. $N$ Z J Zool 1982; 9(4): 451-460. http://dx.doi.org/10.1080/03014223.1 982.10423876 .

Whittaker FH, Schmidt GD, Garcia J. Helminth parasites of some birds in Puerto Rico. Proc Helminthol Soc Wash 1970; 37: 123-124.

Yamaguti S. Systema helminthum. Vol. 1: The digenetic trematodes of vertebrates - Part I. New York: Interscience Publisher; 1958.

Yamaguti S. Systema helminthum. Vol. 2: The cestodes of vertebrates. New York: Interscience Publisher; 1959.

Yamaguti S. Systema helminthum. Vol. 5: Acanthocephala. New York: Interscience Publisher; 1963. 